\title{
STAVOVI O GLAZBENOM OBRAZOVANJU KAO ČIMBENIK GLAZBENOG OBRAZOVANJA BUDUĆIH UČITELJA
}

\section{Lidija Nikolić}

Fakultet za odgojne i obrazovne znanosti, Sveučilište Josipa Jurja Strossmayera u Osijeku, Hrvatska lnikolic@foozos.hr

Cilj rada je razjasniti ulogu stavova o glazbenom obrazovanju u procesu stjecanja kompetencija za podučavanje glazbe kod studenata, budućih učitelja. Uvidom u stavove studenata moglo bi se djelovati na njihovo kvalitetnije glazbeno obrazovanje na studiju i time utjecati na bolju kvalitetu nastave glazbe u mlađim razredima osnovne škole. Pregledom dosadašnjih istraživanja stavova studenata, budućih učitelja o glazbenom obrazovanju htjelo se utvrditi o čemu oni ovise, koji stavovi mogu nepovoljno djelovati na glazbeno obrazovanje na studiju te mogu li se tijekom studija mijenjati. Pokazalo se kako se tijekom nastave glazbe na učiteljskom studiju stavovi studenata mogu mijenjati u pozitivnom smjeru. Međutim, uslijed različitosti uvjeta nastave glazbe na učiteljskim studijima, ali i malobrojnih i metodološki neusklađenih istraživanja, još nije utvrđeno na koji se način i u kojoj mjeri kod studenata učiteljskoga studija može najučinkovitije djelovati na stvaranje pozitivnih stavova o glazbenom obrazovanju.

Ključne riječi: glazbeno obrazovanje, metodika nastave glazbe, nastava glazbe, stavovi, učitelji primarnog obrazovanja, učiteljski studij

\section{Uvod}

Glazbeno obrazovanje neophodan je preduvjet djetetova glazbenoga i estetskoga razvoja, a istraživanja ukazuju na njegov blagotovoran utjecaj na djetetov kognitivni, psihomotorni, socijalni i emocionalni raz- 
voj (Hallam, 2010; Collins, 2013; Hogenes, van Oers i Diekstra, 2014). Upravo su razredni učitelji oni koji mogu svoj djeci omogućiti glazbeno obrazovanje u skladu s propisanim kurikulumom i materijalnim uvjetima škole, a u kojoj će mjeri djeca dobiti priliku za glazbeno obrazovanje najviše ovisi o kompetentnosti učitelja za podučavanje glazbe. Nastavu glazbe s djecom mlađega školskog uzrasta u svijetu najčešće izvode razredni učitelji koji nisu glazbeni specijalisti (Russel-Bowie, 2009; Šulentić Begić i Begić, 2014b). U Hrvatskoj učitelji primarnog obrazovanja izvode nastavu glazbe u prva tri ili četiri razreda osnovne škole, a glazbeno obrazovanje obvezno je za sve studente, buduće učitelje, kroz koncepciju teorijske nastave glazbe, vokalno-instrumentalnu obuku i poduku iz predmetne metodike. Koncepcija glazbenog obrazovanja na učiteljskim studijima u Hrvatskoj podrazumijeva manje razlike između pojedinih sveučilišta u nazivima, satnici i sukcesivnosti kolegija na studiju (Nikolić, 2017, 163), a ishodi učenja povezani su s nastavnom praksom u školi i podrazumijevaju stjecanje znanja o glazbi, vještina slušanja glazbe, pjevanja, sviranja jednog glazbenog instrumenta (sintesajzer, klavir, gitara, harmonika) te stjecanje znanja, iskustava i vještina iz metodike nastave glazbe.

Unatoč tome što koncepcija obaveznog glazbenog obrazovanja svih budućih učitelja u Hrvatskoj pokazuje opsežnije i sadržajnije glazbeno obrazovanje tijekom studija nego u brojnim europskim zemljama (Austrija, Finska, Irska, Italija, Mađarska, Nizozemska, UK i druge, u: Šulentić Begić i Begić, 2014a), dosadašnja istraživanja kvalitete nastave glazbe u primarnom obrazovanju pokazuju kako se nastava glazbe ne izvodi dovoljno kvalitetno (Dobrota, 2002; Svalina, 2015; Šulentić Begić, 2016). Problem kvalitete nastave glazbe s djecom ranoga školskog uzrasta prisutan je u brojnim zemljama Europe i svijeta s istim, sličnim ili različitim odgojno-obrazovnim sustavima (Gajić, 1998; Burdeva, 2005; Wiggins i Wiggins, 2008; Russel-Bowie, 2009; Biasutti, 2010; Ellison i Creech, 2010; Hash, 2010) te upućuje na potrebu istraživanja uzroka nedovoljne kompetentnosti razrednih učitelja, njihovog slabog samopouzdanja za izvođenje nastave glazbe i drugih čimbenika koji mogu uzrokovati slabiju kvalitetu nastave glazbe koju izvode razredni učitelji.

Uzroci slabije kvalitete nastave glazbe koju izvode razredni učitelji traže se prije svega u njihovom glazbenom obrazovanju na studiju za buduće učitelje. Učitelji koji misle da nisu dovoljno dobro pripremljeni 
za podučavanje glazbe pokazuju manjak samopouzdanja i imaju negativne stavove prema svojoj kompetentnosti za podučavanje glazbe (Seddon i Biasutti, 2008). Gifford (1993, 33) je pokazao kako kvalitetu glazbenog obrazovanja učitelja primarnog obrazovanja određuje multidimenzionalna interakcija nekoliko faktora. Faktori koje je Gifford $(1993,39)$ istaknuo ukazuju na složenost učinkovitog i kvalitetnog obrazovanja budućih učitelja za podučavanje glazbe koja ovisi o ranijem glazbenom obrazovanju i iskustvu studenata, stavovima prema glazbi i glazbenom obrazovanju te o kvaliteti glazbenoga obrazovanja na studiju kroz faktore relevantnosti i prirode glazbenih nastavnih predmeta na studiju, nastavnu klimu (eng. classroom learning environment) i preferirane stilove učenja studenata.

Jedan od značajnih faktora o kojemu ovisi kvaliteta glazbenog obrazovanja budućih učitelja su stavovi prema glazbi i glazbenom obrazovanju (Gifford, 1993, 33). Istraživači su potvrdili korelaciju između stavova učitelja primarnog obrazovanja prema glazbi i njihove tendencije za podučavanjem glazbe u razredu (Barişeri, 2000; Holden i Button, 2006; Della Pietra, Bidner i Devaney, 2010).

»... učitelji koji imaju pozitivne stavove prema nastavi Glazbene kulture, glazbenim kompetencijama i usavršavanju imaju višu razinu znanja i više primjenjuju adekvatne metodičke postupke.« (Nikolić, Ercegovac-Jagnjić i Bogunović, 2013, 1054)

Takvi će učitelji svojim učenicima omogućiti više glazbenih iskustava i njihovu bolju kvalitetu nego učitelji s negativnim stavovima o glazbi ili s niskom razinom samoučinkovitosti u podučavanju glazbe (Barry, 1992, 17). Osim toga, učiteljevi se stavovi o glazbi i glazbenom obrazovanju eksplicitno i implicitno prenose na učenike. Studenti, budući učitelji (u nastavku studenti/učitelji), svoje su stavove prema glazbenom obrazovanju razvili prije fakulteta dok su i sami bili učenici tijekom školovanja u osnovnoj i srednjoj školi. Ti stavovi često odražavaju stavove njihovih bivših učitelja i otporni su na promjene, često su neartikulirani i pojednostavljeni (Hash, 2010, 7). Nadalje, studenti/učitelji imaju iskustvo pedagoške prakse u kojoj su sudjelovali kao učenici, a koje je stvorilo uvjerenja o pedagoškoj praksi i stavove o pojedinim segmentima nastavne prakse pojedinih učitelja. Tako studenti/učitelji i prije uključivanja u nastavu glazbe na studiju imaju stavove o nastavi glazbe, odnosno što učitelj treba znati i moći za izvođenje nastave koju su oni iskusili te koje ishode učenja su oni sami postigli i na koji način. 
Uvjerenja studenata/učitelja o važnosti glazbenog obrazovanja u mlađim razredima osnovne škole utjecat će na to kako i u kojoj mjeri će učiti na učiteljskom studiju te na njihove stavove i praksu kada budu podučavali u školi (Russell-Bowie, 2009, 23). Snaga ranijih uvjerenja razlog je tome što će svaki student učiti različitu verziju onoga što ga se podučava (Schmidt, 1998, 19). Stoga su stavovi o glazbenom obrazovanju čimbenik koji značajno utječe na glazbeno obrazovanje na svim razinama. Stavovi prema glazbenom obrazovanju u kontekstu razredne nastave kružno su povezani i zbog toga je važno istražiti kako se može utjecati na razvijanje i stjecanje pozitivnih stavova o glazbenom obrazovanju kako bi oni doprinijeli kvalitetnijem glazbenom obrazovanju budućih učitelja, a time i njihovih budućih učenika.

\section{Stavovi studenata učiteljskih studija o glazbenom obrazovanju}

Stav je stečena, relativno trajna i stabilna organizacija pozitivnih i negativnih emocija, vrednovanja i reagiranja prema osobi, grupi, situaciji, ideji i drugome, a ima složenu psihološku strukturu koju čine kognitivna, emocionalna i konativna komponenta (Petz, 2005, 465). Stavovi se stječu imitacijom i osobnim iskustvom u procesu socijalizacije (Andrilović i Čudina, 1990, 196). Jednom formirani stavovi otporni su na promjene te su trajni jer selektivno djeluju na percepciju, obradu novih informacija i na pamćenje. Andrilović i Čudina $(1990,197)$ navode da mijenjanje stavova zahtijeva strpljivu i opetovanu argumentaciju koja će, osim na intelektualni aspekt stava, djelovati i na emocionalni aspekt. Unatoč uloženom vremenu i naporu, promjena neželjenih stavova često je sasvim neizvjesna. Iz toga razloga u odgojno-obrazovnom radu treba spriječiti nastajanje neželjenih stavova (Andrilović i Čudina, 1990, 197). Škola omogućuje stjecanje kompetencija u okviru propisanog kurikuluma, ali i skrivenog kurikuluma koji »označava vrijednosti koje učenici nauče u školi zbog načina na koji se u školi planira i načina na koji je škola organizirana te kroz osigurana materijalna sredstva« (Pavičić Vukičević, 2013, 119). Osim uloge realizatora propisanog kurikuluma, učitelj ima i ulogu modela za učenike. Učiteljev implicitni sustav vrijednosti oblikuje njegovu odgojno-obrazovnu praksu (Slunjski, 2007, 491).

Koji su stavovi o glazbenom obrazovanju poželjni kod studenata učiteljskog studija? Studenti/učitelji trebali bi imati pozitivne stavove 
o glazbenom obrazovanju, kao i o sposobnosti i potrebi svakoga djeteta da upoznaje glazbu te da se uključi u glazbene aktivnosti. Poželjni stavovi za studente odnose se na poznavanje glazbe i blagotovornog utjecaja glazbenog obrazovanja na djetetov glazbeni, estetski i opći razvoj te pripremu djeteta za uključivanje u društveni i kulturni život. Nadalje, stavovi koji su poželjni za studente/učitelje su oni koji podržavaju stjecanje i razvoj njihovih glazbenih (pjevanje, sviranje, analitičko slušanje glazbe) i metodičkih kompetencija za izvođenje nastave glazbe. Tijekom studija, osim pozitivnim stavovima o glazbi i glazbenom obrazovanju kako djece tako i učitelja, studenti bi trebali izgraditi pozitivne stavove o vlastitim glazbenim sposobnostima i kompetencijama za vođenje nastave glazbe. Time bi potaknuli samopouzdanje koje je potrebno za kvalitetno integriranje glazbe u kurikulum, s obzirom da je dokazana veza između razine samopouzdanja učitelja i uključivanja glazbenih aktivnosti u razredu (Barry, 1992, 21). Samopercepcija vlastite glazbene kompetentnosti studenata ne mora imati uporište $u$ glazbenim znanjima i vještinama koje posjeduju, nego u onome što studenti vjeruju da trebaju posjedovati. Samopercepcija tako ovisi o tome kako studenti/učitelji procjenjuju svoje glazbene kompetencije u odnosu na to uvjerenje i koliko se osjećaju samopouzdano u tom kontekstu.

Stoga se postavljaju sljedeća pitanja:

1. O čemu ovise stavovi studenata/učitelja prema glazbenom obrazovanju te koji stavovi mogu nepovoljno djelovati na njihovo glazbeno obrazovanje na učiteljskom studiju?

2. Je li moguće utjecati na stavove o glazbenom obrazovanju na nastavi glazbe tijekom studija i, ako jest, u kojoj mjeri?

\section{O čemu ovise stavovi studenata/učitelja?}

Stavovi studenata/učitelja o glazbi i glazbenom obrazovanju mogu ovisiti o mnogim čimbenicima. Gifford $(1993,35)$ je istraživao mogućnosti utjecaja na stavove studenata/učitelja te je uz pomoć faktorske analize izdvojio sedam faktora uspješnog glazbenog obrazovanja na učiteljskom studiju. Označio ih je kao: (1) glazbenu sposobnost i sposobnost podučavanja glazbe, (2) važnost glazbe, (3) vrednovanje i poštovanje glazbe, (4) vrednovanje glazbenog obrazovanja na fakultetu, (5) vrednovanje popularne glazbe, (6) podrška za podučavanje glazbe i (7) preferencije za različite tipove glazbenih programa. Spomenuti fak- 
tori pokazuju kako uspješnost glazbenog obrazovanja budućih učitelja ovisi o njihovim glazbenim kompetencijama i kompetencijama za poučavanje glazbe, o njihovom uvažavanju glazbe uopće te vrednovanju glazbenog obrazovanja. Istraživači koji se bave problemom nepovoljnih stavova u glazbenom obrazovanju budućih učitelja ističu probleme slabog ranijeg glazbenog iskustva studenata, neadekvatnih glazbenih programa tijekom obuke na studiju i niskog samopouzdanja u odnosu na njihove glazbene sposobnosti.

Ranije glazbeno iskustvo studenata/učitelja jedan je od važnijih čimbenika u formiranju njihovih stavova o glazbenom obrazovanju. Studenti koji upisuju učiteljski studij imaju već definirane stavove zbog njihovih iskustava tijekom ranijeg školovanja, kao i iskustava u ansamblima, formalnoj ili privatnoj glazbenoj poduci. Studenti koji imaju višegodišnje prethodno glazbeno iskustvo imaju veće samopouzdanje u svoju sposobnost vođenja glazbenih aktivnosti i više vrednuju glazbeni predmet u kurikulumu (Barry, 1992, 20). Della Pietra i sur. $(2010,7)$ potvrdili su pozitivnu korelaciju između ranijeg glazbenog iskustva i pozitivnog stava prema uključenosti glazbe u kurikulum. Spomenuta studija pokazala je da što je veće ranije glazbeno iskustvo, to su pozitivniji stavovi prema uključenosti glazbe u kurikulumu, kao i stavovi o akademskom i socijalnom utjecaju glazbe te stavovi o obimu glazbene poduke i izvođenju glazbe (Della Pietra i sur., 2010, 10). U vezi s glazbenim iskustvom studenata u školi i izvannastavnim glazbenim aktivnostima tijekom ranijeg obrazovanja jest i percipirana i stvarna uspješnost ili neuspješnost studenata koja može ostaviti dugotrajan utjecaj na njihovu profesionalnu budućnost. Iskustvo uspješnosti u ranijem glazbenom obrazovanju i muziciranju pretpostavka je za izgradnju samopouzdanja i samoučinkovitosti te za uživanje u izvođenju koji su neophodni u oblikovanju glazbenika. Kod studenata koji su imali glazbena iskustva koja su dovela do osjećaja neuspjeha ne mogu se očekivati pozitivni stavovi o budućem glazbenom obrazovanju niti želja za podučavanjem glazbe u školi, kao ni kod studenata koji uopće nisu imali glazbena iskustva.

Stavovi koji mogu nepovoljno djelovati na glazbeno obrazovanje tijekom učiteljskog studija, a svakako se ne bi smjeli nastaviti u ranije spomenutoj kružnosti stavova, oni su o glazbenim sposobnostima kao urođenima i nepromjenjivima. Ako studenti/učitelji vjeruju da se glazbene sposobnosti nasljeđuju, a ne stječu, oni će imati uvjerenje da 
se glazbene sposobnosti ne mogu bitno mijenjati, stoga niti glazbeno obrazovanje nije neophodno niti realistično za sve učenike (Wiggins i Wiggins, 2008, 18). Biasutti $(2010,64)$ ističe kako ovo uvjerenje o nepromjenjivosti glazbenih sposobnosti može voditi prema niskim očekivanjima učenika i studenata u razvoju glazbenih vještina jer sebe ne percipiraju glazbeno nadarenima. Nadalje, glazbeno obrazovanje zapadne tradicije donijelo je visoke standarde glazbene produkcije te mišljenje kako se glazbom trebaju baviti samo glazbeno nadarene osobe, dakle na djelu je bipolarnost shvaćanja muzikalnosti. Svojevrsni glazbeni elitizam zapadne glazbene tradicije utjecao je na formiranje stava o superiornosti formalnog glazbenog obrazovanja koje vodi osjećaju nedostatnosti kod onih koji nisu imali takvo obrazovanje (O'Neill, 2006, 462). Stoga studenti koji vjeruju da nisu glazbeno nadareni manje će se glazbeno razviti i oformit će stavove o svojoj nekompetentnosti za podučavanje glazbe u razredu.

U vezi sa spomenutim stavom o nepromjenjivosti glazbenih sposobnosti, istraživanja su pokazala da studenti/učitelji imaju uvjerenje da je podučavanje glazbe u razredu specijalna disciplina te da je za to potrebna darovitost $u$ sviranju glazbenog instrumenta i čitanju glazbene notacije (Mills, 1989, 133; Hennessy, 2000, 188). Učitelji, kasnije u praksi, uspoređuju svoje glazbene vještine s predmetnim nastavnicima glazbe (Seddon i Biasutti, 2008, 418), što još više pojačava njihovu percepciju nedostatnosti. Neki studenti misle kako trebaju imati glazbene vještine kao što je sviranje klavira, tečnost u čitanju notnog zapisa i detaljno poznavanje klasične glazbe, koje je obično povezano s glazbenim specijalistima, ako žele biti učinkoviti kao učitelji glazbe u razrednoj nastavi (Mills, 1989, 133). Mills $(1989,133)$ tvrdi da ovo pretjerano mišljenje o posjedovanju potrebnih glazbenih vještina kod nekih studenata uzrokuje manjak samopouzdanja u njihovu sposobnost podučavanja glazbe. Niska samopercepcija kompetencija kod studenata/učitelja i njihovo slabo samopouzdanje kao učitelja glazbe te ograničenost u glazbenim kompetencijama i vještinama podučavanja glazbe uzrokuju manje uživanje i vrednovanje glazbe i glazbenog obrazovanja (Gifford, 1993, 33).

Iz navedenoga možemo zaključiti kako su stavovi studenata/učitelja o glazbenom obrazovanju rezultat složenog sklopa okolnosti: društvenog i kulturnog okruženja, stvarnog glazbenog potencijala i sposobnosti, znanja i vještina studenata/učitelja, njihovog glazbenog 
obrazovanja i iskustava aktivnog muziciranja prije i za vrijeme studija te psiholoških konstrukta samoprocjene, samopouzdanja, samoučinkovitosti i očekivanja.

\section{Je li moguće utjecati na stavove na nastavi glazbe tijekom učiteljskog studija?}

Istraživanja problema na koji način i u kojoj mjeri nastava glazbe na studiju može utjecati na formiranje poželjnih stavova budućih učitelja o glazbi i glazbenom obrazovanju pokazuju različite rezultate. Dobrota $(2016,44)$ je u svom istraživanju stavova studenata o glazbi i glazbenoj nastavi zaključila kako studenti učiteljskoga studija imaju pozitivnije stavove nego studenti koji nemaju nastavu glazbe na studiju. Autorica to objašnjava pozitivnim utjecajem izloženosti umjetničkoj glazbi tijekom visokoškolskog obrazovanja (Dobrota, 2016, 41). Barişeri (2000) je istraživao samopouzdanje studenata/učitelja u vlastita glazbena znanja i vještine podučavanja glazbe u razredu te stavove o vrijednosti glazbe za dječji razvoj među engleskim i turskim studentima učiteljskih studija. U spomenutom istraživanju nije utvrđena statistički značajna razlika u samopouzdanju i stavovima studenata nakon jednog semestra nastave glazbe (Barişeri, 2000, 128). Niti Fisher, Rutkowski i Shelley (1992, u: Austin, 1995, 8) nisu pronašli značajnu promjenu u stavovima kod studenata/učitelja nakon jednog semestra nastave glazbe. Austin i Reinhardt $(1999,28)$ otkrili su vrlo malu promjenu u stavovima studenata/učitelja o glazbenom obrazovanju.

Različiti rezultati istraživanja utjecaja nastave glazbe na stavove studenata nisu iznenađujući jer su studije, provedene na različitim fakultetima koji obrazuju buduće učitelje, naišle na značajne probleme s obzirom na metodologiju koji se očituju u samim mjernim instrumentima te problemu oskudnih izvještaja o istraživanjima koji ne daju dovoljno podataka o samoj nastavi kao interventnoj varijabli. Ključan problem istraživanja stavova studenata/učitelja o glazbenom obrazovanju je to što se nastava glazbe na studiju u različitim zemljama, ali i među fakultetima u istoj državi, kao interventna varijabla, razlikuje u odnosu na nastavni sadržaj, postavljene ishode učenja, nastavne metode, a najviše na sam tip nastave, odnosno radi li se o temeljnim glazbenim kolegijima (teorija glazbe, glazbene vještine sviranja, pjevanja, skladanja) ili nastavi metodike nastave glazbe. Budući da se sami kolegiji bitno razlikuju, njihov je utjecaj na stavove studenata također različit. 
S obzirom na navedene poteškoće nije moguće izložiti precizne rezultate istraživanja, ali ih je moguće razvrstati prema kriterijima: koji su stavovi istraživani i kojem su obliku nastave glazbe studenti bili izloženi, odnosno jesu li studenti pohađali temeljne glazbene kolegije (eng. fundamental courses) ili metodiku nastave glazbe (eng. method courses) te trajanje nastave čiji se utjecaj mjeri, i to kod istraživača koji su takve podatke naveli u izvještaju o istraživanju.

Jennaeret (1997) je provela studiju sa studentima/učiteljima na učiteljskim studijima u Australiji i SAD u kojoj je istraživala utjecaj nastave temeljnih glazbenih predmeta na nekoliko ishoda među kojima su i stavovi i uvjerenja o glazbenom obrazovanju. Studenti su sudjelovali u glazbenoj nastavi koja je uključivala glazbeno izvođenje, skladanje i aktivnosti slušanja glazbe (Jennaeret, 1997, 38). Rezultati ove studije pokazali su pozitivan utjecaj temeljnih glazbenih predmeta na stavove o glazbi nakon dva semestra nastave glazbe. Također, Austin $(1995,11)$ je istraživao učinke nastave temeljnih glazbenih predmeta na stavove studenata/učitelja i njihovu motivaciju, ali nije zabilježena promjena nakon nastave koja je trajala jedan semestar. Međutim, Gifford (1993, 36) je u svojoj studiji zaključio kako je jedan semestar nastave temeljnog glazbenog predmeta djelovao na studente/učitelje tako da su oni cijenili glazbu manje nego prije nastave.

U istraživanju Lewisa (1991, u: Austin, 1995, 8) pokazalo se kako je tijekom jednog semestra nastava metodike nastave glazbe imala pozitivan utjecaj na stavove prema glazbenom obrazovanju (prirodi glazbenih sposobnosti, važnosti glazbe u kurikulumu, sposobnosti učitelja za podučavanje glazbe u razredu). Barry $(1992,20)$ je zabilježila pozitivne stavove o glazbenom obrazovanju studenata/učitelja koji su pohađali nastavu metodike (stavovi prema podučavanju glazbe i ulozi glazbe u kurikulumu mlađih razreda osnovne škole). Istraživanje utjecaja pohađanja metodike nastave glazbe $u$ trajanju od tri mjeseca pokazalo je značajne i pozitivne promjene u stavovima studenata/učitelja prema podučavanju glazbe u razredu (Nart, 2016, 50).

Utjecaj nastave glazbe na učiteljskim studijima na stavove prema glazbenom obrazovanju istraživan je i kada je nastava glazbe sadržavala temeljne glazbene sadržaje i integraciju glazbe u kurikulum. Berke i Colwell $(2004,30)$ uočili su pozitivnu promjenu stavova prema glazbenom obrazovanju nakon jednog semestra ranije opisane nastave glazbe. Phillips i Vispoel (1990) su izvijestili o poboljšanjima u stavovima pre- 
ma pjevanju nakon jednog semestra kada je podučavanje pjevanja bilo implementirano u nastavu metodike nastave glazbe. Siebenaler (2006) je proveo istraživanje među studentima/učiteljima nakon jednog semestra nastave glazbe koja je objedinjavala temeljne glazbene sadržaje i metodičke sadržaje. Nakon provedene nastave uočene su značajne pozitivne razlike $u$ razini ugode kod studenata $u$ vezi s izvođenjem različitih glazbenih aktivnosti u razredu (Siebenaler, 2006, 17). Upravo osjećaj ugode u vođenju glazbenih aktivnosti može utjecati na pozitivnije stavove studenata prema podučavanju glazbe djelujući na emocionalnu komponentu stavova.

Dakle, dosadašnja malobrojna istraživanja utjecaja nastave glazbe na učiteljskim studijima na stavove studenata o glazbenom obrazovanju pokazuju različite rezultate. Studije koje su pokazale pozitivne trendove u razvoju stavova o glazbenom obrazovanju provedene su praćenjem učinkovitosti nastave onih nastavnih predmeta glazbe na studiju koji povezuju metodičke sadržaje i iskustva s učenjem znanja o glazbi i glazbenih vještina. Nastava metodike nastave glazbe povećava samopercepciju kompetentnosti i samopouzdanja kod studenata/učitelja, a istovremeno im pomaže u stjecanju znanja o glazbi, praktičnih iskustava i učinkovitih strategija podučavanja glazbe (Chokera, 2016, 14), stoga se mogu očekivati i povoljniji stavovi o glazbenom obrazovanju kod studenata/učitelja koju su takvu nastavu pohađali. Nabrojane studije (osim Jennaeretine i Barryne studije) pratile su učinak nastave glazbe kroz jedan semestar, a nameće se pitanje kakvi bi se rezultati zabilježili kroz duže vremensko razdoblje glazbenog obrazovanja. Istraživanja stavova studenata/učitelja o glazbenom obrazovanju koja su pratila učinak temeljnih glazbenih predmeta ukazala su na problem pratećih pojava procesa stjecanja vokalno-instrumentalnih kompetencija te učenja elementarnih znanja o glazbi na učiteljskom studiju. Ograničeno vrijeme glazbenog obrazovanja na učiteljskim studijima za razvijanje senzitivnosti u odnosu na glazbu čini da se nastavnik glazbe na studiju doživljava više kao glazbeni kritičar nego kao model vještog glazbenika i pedagoga (Gifford, 1993, 45). Kao problem nastave glazbe na učiteljskom studiju ističu se nezainteresiranost studenata za učenje glazbe i nedovoljno vježbanje sviranja i pjevanja (Nikolić, 2017, 175), koje je neophodno za stjecanje kompetencija za vođenje nastave glazbe u razredu, te vrlo izražen problem neugode kod studenata kada trebaju individualno izvoditi glazbu jer to doživljavaju kao ispitnu situaciju (Šenk i 
Ercegovac-Jagnjić, 2004, 123). Čini se da bilo koji pokušaj obučavanja studenata/učitelja kao glazbenika može rezultirati poboljšanjem vještina podučavanja glazbe, ali kao sporedne pojave mogu se pojaviti manje vrednovanje i uživanje u procesu učenja glazbe te veći otpor prema uključenosti u glazbeno obrazovanje (Gifford, 1993, 45).

\section{Zaključak}

Stavovi prema glazbenom obrazovanju važan su čimbenik glazbenog obrazovanja budućih učitelja. Stavovi studenata učiteljskog studija o glazbenom obrazovanju ovise o ranijem glazbenom obrazovanju i iskustvima muziciranja, njihovoj stvarnoj glazbenoj kompetentnosti, ali i samoprocjeni, samoučinkovitosti, očekivanjima i samopouzdanju u vlastite glazbene kompetencije i kompetencije za podučavanje glazbe u razredu te obrazovnom, društvenom i kulturnom okruženju. Nepovoljni stavovi o glazbenom obrazovanju kod studenata, budućih učitelja, odnose se na stavove o nepromjenjivosti glazbenih sposobnosti, mišljenje kako je glazbeno obrazovanje namijenjeno samo glazbeno nadarenima te kako su učitelji nedovoljno glazbeno kompetentni za podučavanje glazbe u razrednoj nastavi jer ne posjeduju glazbene kompetencije koje imaju glazbeni specijalisti. Takvi stavovi mogu nepovoljno djelovati na studentovo glazbeno obrazovanje na studiju zbog složene psihološke strukture stavova koja se odražava u selektivnoj percepciji, obradi i pamćenju novih informacija te angažmanu i ponašanju studenta. Različita su istraživanja pokazala kako se tijekom nastave glazbe na učiteljskom studiju mogu mijenjati stavovi o glazbenom obrazovanju u pozitivnom smjeru, ali ta su istraživanja malobrojna i metodološki neusklađena.

Zbog metodoloških problema, ali i različitih uvjeta nastave glazbe na učiteljskim studijima, još nije utvrđeno na koji se način i u kojoj mjeri kod studenata učiteljskoga studija može najučinkovitije djelovati na stvaranje pozitivnih stavova o glazbenom obrazovanju. Stoga je, kako bi se djelovalo na veću kompetentnost budućih učitelja za podučavanje glazbe, potrebno istražiti kakvi su stavovi studenata učiteljskih studija o glazbi i glazbenom obrazovanju kada upišu učiteljski studij, o čemu ovise i kako se stavovi odražavaju na uspješnost glazbenog obrazovanja na studiju te koliko je tijekom studija moguće djelovati na stvaranje povoljnih odnosno transformaciju nepovoljnih stavova. Buduća istraži- 
vanja problema stavova o glazbenom obrazovanju trebala bi podrobno izvještavati o kvaliteti i kvantiteti nastave glazbe čiji se utjecaj prati kako bi se omogućila usporedba rezultata različitih istraživača i na taj način došlo do relevantnih spoznaja o mogućnostima utjecaja na formiranje primjerenih stavova i transformiranje nepovoljnih stavova o glazbenom obrazovanju koja održavaju trenutnu kružnost stavova učenik-student-učitelj-učenik i tako omogućiti pozitivnu promjenu u glazbenom obrazovanju budućih učitelja.

S obzirom na slabu istraženost i veliku složenost koncepta stavova te važnost izloženih različitih čimbenika, modeli glazbenog obrazovanja i pristup nastavnika glazbe na učiteljskim studijima trebaju potražiti nove oblike i pristupe koji će kružnoj povezanosti stavova učitelja i učenika o glazbi i glazbenom obrazovanju dati afirmativna svojstva. Uz stjecanje kompetencija za vođenje nastave glazbe, potrebno je razviti i odgovarajuće stavove studenata prema važnosti glazbe i nastave glazbe za buduće učenike te samopouzdanje studenata za izvođenje nastave glazbe (Nikolić, 2017, 165). Za postizanje spomenutih ishoda nastave glazbe na učiteljskom studiju "potrebno je provoditi evaluaciju postignuća studenata, učinkovitosti metoda i postupaka, nastavne klime, praćenje mijenjanja stavova studenata o glazbi i nastavi glazbe te pristupa nastavnika glazbe na studiju « (Nikolić, 2017, 165-166). Nastavnik glazbe na učiteljskom studiju treba uzeti u obzir ranije glazbeno iskustvo i osobne teorije studenata koje će informirati nastavnika o stavovima i obrazovanju studenata. Kako bi se razvijali pozitivni stavovi studenata o glazbenom obrazovanju, potrebno je od prvog susreta nastavnika glazbe sa studentima/učiteljima argumentiranim pristupom ohrabrivati studente i uvjeriti ih kako su sposobni postići postavljene ishode učenja glazbe na studiju ostvarivanjem suradničkog odnosa sa studentima, stvaranjem pozitivne nastavne klime i njegovanjem otvorene i korektne komunikacije. Uz razvoj pozitivnih stavova o glazbenom obrazovanju koji će im olakšati stjecanje glazbenih kompetencija i kompetencija za poučavanje glazbe, potrebno je omogućiti studentima iskustvo glazbene uspješnosti i razvijanja samoučinkovitosti i samopouzdanja koji su potrebni kako bi se učitelj osjećao kompetentnim za izvođenje nastave glazbe u razredu. Razvijanjem pozitivnih stavova studenata, budućih učitelja o glazbi uopće i glazbi u kurikulumu te njihovim vrednovanjem glazbe stvaraju se pretpostavke za kvalitetniju nastavu glazbe u mlađim razredima osnovne škole. 
U ovom radu istaknuta je važnost ranijeg glazbenog iskustva za stvaranje pozitivnih stavova prema glazbenom obrazovanju. Stoga učitelji i nastavnici glazbe te sveučilišni nastavnici glazbe na učiteljskim studijima trebaju učenicima odnosno studentima omogućiti pozitivna iskustva muziciranja te kvalitetnu i poticajnu nastavu glazbe kako bi se stvorile pretpostavke za njihove pozitivne stavove o glazbenom obrazovanju, izgradnju samopouzdanja, samoučinkovitosti i uživanje u izvođenju glazbe. Učitelji i nastavnici glazbe trebali bi osvijestiti i značaj negativnih iskustava učenika u glazbi kao i potrebu mijenjanja društveno prihvaćenih stavova o nepromjenjivosti glazbenih sposobnosti te u nastavnoj praksi stvarati prilike za upoznavanje glazbe i muziciranje svakoga djeteta.

\section{Literatura}

Andrilović, Vlado i Čudina, Mira (1990), Osnove opće i razvojne psihologije, Zagreb: Školska knjiga.

Austin, James R. (1995), »Future classroom teachers' ability self-perceptions and attributional responses to failure in music: Do music fundamentals classes make a difference? «, Research Perspectives in Music Education: A Bulletin of the Florida Music Educator Association, 5, str. 6-15.

Austin, James i Reinhardt, Deborah (1999), »Philosophy and advocacy: An examination of preservice music teachers' beliefs «, Journal of Research in Music Education, 47(1), str. 18-30. https://doi.org/10.2307/3345825

Barişeri, Nutruğ (2000), Primary music teacher education in England and Turkey, doktorska disertacija, Durham University. Dostupno na:

http://etheses.dur.ac.uk/4287/1/4287_1807.pdf [27. 12. 2017.]

Barry, Nancy. H. (1992), »Music and education in the elementary music methods class «, Journal of Music Teacher Education, 2(1), str. 16-23.

doi: https://doi.org/10.1177/105708379200200104

Berke, Melissa i Colwell, Cynthia M. (2004), »Integration of music in the elementary curriculum: Perceptions of preservice elementary education majors «, Update: Applications of Research in Music Education, 23(1), str. 22-33. doi: https://doi.org/10.1177/87551233040230010104

Biasutti, Michele (2010), »Investigating trainee music teachers' beliefs on musical abilities and learning: a quantitative study«, Music Education Research, 12(1), str. 47-69. doi: https://doi.org/10.1080/14613800903568262

Burdeva, Tanya (2005), »The competence of music teachers at the elementary schools«, Trakia Journal of Sciences, 3(8), str. 4-6. Dostupno na:

http://www.uni-sz.bg/tsj/vol3No8_1/T.Burdeva.pdf [15. 11. 2017.] 
Chokera, Abbey Kaigera (2016), »The effects of a music methods course on Kenyan pre-service generalist primary school teachers' perceived confidence and competence to teach music«, doktorska disertacija, University of Florida. Dostupno na: https://pqdtopen.proquest.com/doc/1847568000.html?FMT=ABS [27. 1. 2018.]

Collins, Anita (2013), »Music education and the brain: What does it take to make a change? «, Update: Applications of Research in Music Education, 32(2), str. 4-10. doi: https://doi.org/10.1177/8755123313502346

Della Pietra, Christopher J.; Bidner, Sara i Devaney, Thomas A. (2010), »Preservice elementary classroom teachers' attitudes toward music in the school curriculum and teaching music «, Research \& Issues in Music Education, 8(1), Article 4. Dostupno na:

https://ir.stthomas.edu/cgi/viewcontent.cgi?article=1028\&context=rime [15. 11 . 2017.]

Dobrota, Snježana (2002), »Glazbena nastava u razrednoj nastavi«, Tonovi, 39, str. 67-79.

Dobrota, Snježana (2016), »Stavovi studenata prema umjetničkoj glazbi i glazbenoj nastavi«, Školski vjesnik: časopis za pedagogijsku teoriju i praksu, 65, tematski broj, str. 33-47.

Ellison, Jessica i Creech, Andrea (2010), »Music in the primary school«, u: Hallam, Susan i Creech, Andrea (ur.), Music Education in the $21^{\text {st }}$ Century in the United Kingdom, London: Institute of Education, University of London, str. 211-227.

Gajić, Slavko (1998), »Kakva je i od čega zavisi nastava muzičke kulture u nižim razredima osnovne škole«, Nastava $i$ vaspitanje, 47(1), str. 50-61.

Gifford, Edward (1993), »The musical training of primary teachers: Old problems, new insights and possible solutions «, British Journal of Music Education, 10, str. 33-46. doi: https://doi.org/10.1017/S0265051700001418

Hallam, Susan (2010), »The power of music: Its impact on the intellectual, social and personal development of children and young people«, International Journal of Music Education, 28(3), str. 269-289. doi: https://doi.org/10.1177/0255761410370658

Hash, Phillip M. (2010), »Preservice classroom teachers' attitudes toward music in the elementary curriculum«, Journal of Music Teacher Education, 19(2), str. 6-24. doi: https://doi.org/10.1177/1057083709345632

Hennessy, Sarah (2000), »Overcoming the red-feeling: the development of confidence to teach music in primary school amongst student teachers «, British Journal of Music Education, 17(2), str. 183-196. doi: https://doi.org/10.1017/S0265051700000243 
Hogenes, Michel; van Oers, Bert i Diekstra, René F. W. (2014), »The impact of music on child functioning«, The European Journal of Social \& Behavioural Sciences, 135, str. 1507-1526. doi: http://dx.doi.org/10.15405/ejsbs.135

Holden, Hilary i Button, Stuart (2006), »The teaching of music in the primary school by the non-music specialist«, British Jourmal of Music Education, 23(1), str. 23-38. doi: http://dx.doi.org/10.1017/S0265051705006728

Jeanneret, Neryl (1997), »Model for developing primary teachers' confidence to teach music«, Bulletin of the Council for Research in Music Education, 133, str. 37-44. Dostupno na: http://www.jstor.org/stable/40318837 [12. 11. 2017.]

Mills, Janet (1989), »The generalist primary teacher of music: A problem of confidence«, British Journal of Music Education, 6(2), str. 125-138. doi: https://doi.org/10.1017/S0265051700007002

Nart, Sevan (2016), »A comparison of pre-service elementary classroom teachers' attitudes and self-efficacy beliefs towards teaching music measured before and after the 'Teaching Music Course' ", Proceedings of IAC-GETL in Budapest, Praque: Czech Technical University, str. 43-52. Dostupno na: https://www.academia.edu/30539415 [27. 1. 2018.]

Nikolić, Lidija (2017), »Evaluation of the model of music education of future teachers of primary education«, Školski vjesnik: časopis za pedagogijsku teoriju i praksu, 66(2), str. 179-179.

Nikolić, Lidija; Ercegovac-Jagnjić, Gordana i Bogunović, Blanka (2013), »Refleksije obrazovnih modela učitelja razredne nastave na elemente glazbenih kompetencija«, Hrvatski časopis za odgoj i obrazovanje/Croatian Journal of Education, 15(4), str. 1033-1056.

O’Neill, Susan A. (2006), »Positive youth musical engagement«, u: McPherson, Gary E. (ur.), The Child as a Musician, Oxford University Press, str. 461-474.

Pavičić Vukičević, Jelena (2013), »Uloga implicitne teorije nastavnika u skrivenom kurikulumu suvremene škole«, Pedagogijska istraživanja, 10(1), str. 119-133.

Petz, Boris (ur.) (2005), Psihologijski rječnik, Jastrebarsko: Naklada Slap.

Phillips, Kenneth H. i Vispoel, Walter P. (1990), »The effects of class voice and breath management instruction on vocal knowledge, attitudes, and vocal performance among elementary education majors«, The Quarterly, 1(152), str. 96-105. (Reprinted with permission in Visions of Research in Music Education, 16(1), Summer, 2010). Dostupno na:

http://www-usr.rider.edu/ vrme/v16n1/visions/spring11 [27. 12. 2017.]

Russell-Bowie, Deirdre (2009), »What me? Teach music to my primary class? Challenges to teaching music in primary schools in five countries«, Music Education Research, 11(1), str. 23-36. doi: https://doi.org/10.1080/14613800802699549 
Schmidt Margaret (1998), »Defining 'good' music teaching: Four student teachers' beliefs and practices«, Bulletin of the Council for Research in Music Education, 138, str. 19-46.

Seddon, Frederick i Biasutti, Michele (2008), »Non-music specialist trainee primary school teachers' confidence in teaching music in the classroom «, Music Education Research, 10(3), str. 403-421. doi: https://doi.org/10.1080/14613800802280159

Siebenaler, Dennis (2006), »Training teachers with little or no music background: Too little, too late?«, Update: Applications of Research in Music Education, 24(2), str. 14-22. doi: https://doi.org/10.1177/87551233060240020102

Slunjski, Edita (2007), »Vrijednosti učitelja kao temelj odgojno-obrazovnog procesa«, u: Babić, Nada (ur.), Kompetencije i kompetentnost učitelja: Osijek, 18. i 19. travnja 2007.: zbornik radova / Competences and Teacher Competence: Osijek, 18th-19th April 2007: Proceedings, Osijek: Sveučilište Josipa Jurja Strossmayera, Učiteljski fakultet u Osijeku; Kherson State University, Ukraine, str. 491-499.

Svalina, Vesna (2015), Kurikulum nastave glazbene kulture i kompetencije učitelja za poučavanje glazbe, Osijek: Sveučilište Josipa Jurja Strossmayera u Osijeku, Fakultet za odgojne i obrazovne znanosti.

Šenk, Lidija i Ercegovac-Jagnjić, Gordana (2004) »Poteškoće u nastavi sviranja na učiteljskom studiju«, Život $i$ škola: časopis za teoriju i praksu odgoja $i$ obrazovanja, 12, str. 116-124.

Šulentić Begić, Jasna (2016), »Glazbene kompetencije studenata učiteljskog studija«, Napredak: časopis za pedagogijsku teoriju i praksu, 157(1-2), str. 55-69.

Šulentić Begić, Jasna i Begić, Amir (2014a), »Glazbena naobrazba učitelja primarnog obrazovanja u europskim državama«, u: Prskalo, Ivan; Jurčević Lozančić, Ana i Braičić, Zdenko (ur.), 14. Dani Mate Demarina - Suvremeni izazovi teorije i prakse odgoja i obrazovanja / 14th Mate Demarina Days Contemporary Challenges to Educational Theory and Practice, Zagreb: Učiteljski fakultet, Sveučilište u Zagrebu, str. 285-294.

Šulentić Begić, Jasna i Begić, Amir (2014b), »Nastava glazbe u primarnom obrazovanju u europskim državama«, Metodički ogledi: časopis za filozofiju odgoja, 21(1), str. 23-45.

Wiggins, Robert A. i Wiggins, Jackie (2008), »Primary music education in the absence of specialists«, International Journal of Education \& the Arts, 9(12), str. 1-26. Dostupno na: http://www.ijea.org/v9n12/ [15.1.2018.] 


\section{ATTITUDES ABOUT MUSIC EDUCATION AS A FACTOR OF MUSIC EDUCATION FOR FUTURE PRIMARY SCHOOL TEACHERS}

\section{Lidija Nikolić}

The aim of this paper is to clarify the role of attitudes towards music education in the process of acquiring competences for teaching music of students, future primary school teachers in order to affect on their higher quality of the music education at the faculty and thus improve the quality of music teaching in school. By reviewing the former researches of students' attitudes about music education, it was intended to determine what they depend on, which attitudes may adversely affect the music education in the teaching studies, and whether they can be changed during the study. It has been shown that during the teaching of music in a teaching studies attitudes of students can be changed in a positive direction. However, due to the differences in the conditions of music teaching in teacher studies, as well as the small number of methodological uncoordinated researches, it has not yet been established in what manner and to what extent one can most effectively act toward development of positive attitudes of the students about music education.

Key words: music education, music teaching methodology, music teaching, attitudes, primary school teacher, teaching studies 